\title{
enew \\ Open Innovation Business Model as an Opportunity to Enhance the Development of Sustainable Shared Mobility Industry
}

\author{
Katarzyna Turoń
}

check for updates

Citation: Turoń, K. Open Innovation Business Model as an Opportunity to Enhance the Development of Sustainable Shared Mobility Industry. J. Open Innov. Technol. Mark. Complex. 2022, 8, 37. https://doi.org/10.3390/ joitmc 8010037

Received: 7 January 2022

Accepted: 8 February 2022

Published: 10 February 2022

Publisher's Note: MDPI stays neutral with regard to jurisdictional claims in published maps and institutional affiliations.

Copyright: (C) 2022 by the author. Licensee MDPI, Basel, Switzerland. This article is an open access article distributed under the terms and conditions of the Creative Commons Attribution (CC BY) license (https:// creativecommons.org/licenses/by/ $4.0 /)$.
Department of Road Transport, Faculty of Transport and Aviation Engineering, Silesian University of Technology, 40-019 Katowice, Poland; katarzyna.turon@polsl.pl

\begin{abstract}
The shared mobility services market is growing and changing very rapidly. Many novelties are introduced to the systems, ranging from improvements to the services already offered to services referred to as innovative. Since the following years are to bring significant development of mobility as a service (MaaS) systems, data sharing, and cooperation on the mobility market, the article is dedicated to check whether the current business models of the industry are ready for the open innovations implementations. The article aimed to analyze the business models of shared mobility systems along with their presentation in the form of CANVAS models and to investigate whether the models contain aspects of open innovation. Moreover, the article presents its own value-added open business model prepared for the whole shared mobility market. The paper also identifies a set of open innovations that can be implemented by all types of shared mobility operators. It proposed the basis that operators can use when developing their own open business models. The developed research is an original contribution to filling the research gap concerning the approach to open innovation by operators of all types of shared mobility services available on the market. The results show that car-sharing service providers are the biggest opponents of open innovation. On the other hand, the most 'open' systems are bike-sharing services. The conducted research may support operators in the process of transforming their businesses into more accessible for users. It also helps to develop the open innovation concept to create more sustainable shared mobility systems along the lines of collaborative economy assumptions.
\end{abstract}

Keywords: shared mobility; collaborative economy; open innovation; business models; data sharing; transportation engineering; mobility management; open shared mobility systems; sustainable transport systems

\section{Introduction}

Shared mobility services, i.e., short-term bicycles, cars, and scooter rentals, have become widely available in modern cities on six continents of the world. In recent years, the service has gained great popularity around the world. Statistics show that the value of the shared mobility market is USD 104.95 billion [1]. The increased interest in using these services is mainly related to the availability of vehicles around-the-clock in cities [2]. Systems are increasingly distributed within cities and better correlated with urban public transport [3]. The systems are also associated with flexibility and independence in movement provided by shared vehicles [4]. Shared mobility services are generally well perceived by the public, although there are also negative opinions about, for example, overly complicated vehicle rental processes, users' concerns about the leakage of personal data, or a lower sense of privacy, security, and comfort compared to passenger cars [5].

This is the basis for searching for all possibilities of system improvements to correct their operation. Such improvements include, for example, the successive replacement of the vehicle fleet not only with electric or hybrid vehicles but also supplementing the fleet with small city vehicles or premium cars in the case of car-sharing [6]. Or the replacement of bicycles and scooters for more secure and tailored to the needs of users, e.g., with additional 
luggage, space for a smartphone, etc. in the case of bike- and scooter-sharing [7]. Another option is to create additional parking spaces and dedicated vehicles from infrastructure shared mobility systems [8]. Various types of changes in the price lists of shared mobility services are also possible, including the provision of package services [9]. There are also special offers or additional services for system subscribers [10]. The search for possible improvements was also related to the particularly unfavorable period for transport during the COVID-19 pandemic [11]. It was related to the various types of restrictions introduced during the pandemic in the form of:

- Lockdowns to reduce citizen movement [12];

- The need to maintain social distance [13];

- Closing of many key public utilities [14];

- Switching to remote work mode [15],

Which significantly influenced the change of transport mobility and the existing habits of the society around the world. Scientists noted that the outbreak of the pandemic therefore brought many economic, social, and environmental challenges to the shared mobility industry [16]. From the issue of the need to ensure an adequate level of the sanitary regime to the need to deal with the fear of using public transport in society [17]. In addition, the risks associated with the use of transport in a pandemic are addressed [18]. It was also emphasized that various types of management solutions should be sought to ensure the efficient functioning of transport systems in the pandemic and post-pandemic periods [19], and to focus on appropriate education on how enterprises should do it [20].

When analyzing the shared economy market, of which shared mobility services are a part, I noticed a significant increase in the creation of various types of business practices [11]. However, it is worth noting that, in line with an idea of the sharing economy, practices should be customer-oriented, not only profitable for the organization [21]. The assumptions of the sharing economy also emphasize the importance of the value offered by companies to society [22]. Moreover, it is worth emphasizing that in line with the sharing economy, companies should rely on the openness of data and resources and should be an integral part of the functioning of their transport services [11]. Furthermore, Sutherland and Jarrahi emphasize that any Shared Mobility Service Platforms should operate on the basis of decentralized sharing contexts and that there is a real need to research current practice analyses and strive to standardize the principles of data sharing [23]. On the other hand, Jorge-Vázquez notes that in the era of the data-sharing economy in the digital age, special attention should be paid to the approach to economic and legal issues, as well as the concept of company management [24]. Regarding the sharing economy issues with the shared mobility market, it should be stated that it is an excellent market for sharing data and relying on open business models due to, among others:

- The increasing popularity of mobility as a service system [25];

- Internationalization and intercity of shared mobility services [26];

- Rapidly growing market competition [27];

- The emergence of newer and newer transport solutions, e.g., scooter-sharing, Segwaysharing [28].

Noticing such great opportunities for the connection of shared mobility with open business, I assumed that the implementation of innovation, especially open innovation applied in the business models, may positively affect the growth of interest in shared mobility services and thus translate into achieving even greater transport sustainability which can be of particular importance in a difficult pandemic time. Based on this assumption, I made a detailed literature review of the business models used in shared mobility systems to identify research gaps concerning the issues of open innovation and the sharing economy. I identified that the topic of business models in shared mobility systems is a popular topic in the scientific community. For example, Münzel et al. in their article, they indicated the existence of several main business models concerning car-sharing, specifying cooperative car-sharing, business-to-consumer (B2C) roundtrip, and one-way models, as 
well as peer-to-peer (P2P) models and making the model addictive business based on the specific form of services offered [29]. In contrast, Cohen and Kietzmann further characterized in detail the existence of the non-profit business model [30]. In turn, Franken in his considerations indicated the existence of a hybrid form in the form of internet platforms operating for B2B and B2C entities [31]. In other works, Shaheen and Cohen indicated specific business motivations of individual business models of the systems, pointing to the existence of neighborhood, vacation, university, and others [32]. Therefore, the literature pointed only to analyses of business models of shared mobility in terms of the type of services provided. The authors of Coenegrachts et al. who analyzed business models from the point of view of first-/last-mile, clustered, point-of-interest (POI), hybrid, and closed mobility hub networks, provide alternative solutions to integrate sustainable transportation modes into a coherent network, enabling multi- and intermodal travel behavior, and supporting interoperability, sustainable land use, and ensured access to shared (electric) travel modes [33]. However, they did not address the subject of open business models and open innovation. The only works that referred to open innovation in their subject matter were the articles by the authors of Turon and Kubik analyzed the practices implemented into business models by shared mobility operators during the COVID pandemic [11]. In turn, in [34] they considered the approach of operators of shared mobility services to the subject of open innovation and the implementation of Mobility as a Service systems.

The conducted literature review confirmed that the subject of open innovations is not popular among scientists, and the subject of open business models is a significant research gap. Due to this, my interest was aroused by the business models introduced by operators and checking what elements are considered in the business models of the systems and whether they incorporate open innovation.

Based on this assumption, this article is devoted to analyzing the business models of shared mobility systems along with presenting them in the form of CANVAS models, to check whether the models contain aspects of open innovation, and to developing open business models for shared mobility systems. The proposed research is an original contribution to filling the research gap concerning the approach to open innovation by operators of all types of shared mobility services available on the market. The conducted research may support operators in the process of transforming their businesses into a more accessible form of service for users. Moreover, it fills the research gap in the proposed value-added open shared mobility business model.

This work has been divided into five chapters that successively present the theoretical approach to open innovations and their place in business models, methodology and my own research, results, and discussions, and a summary.

\section{Open Innovation Business Models}

Business models are rules that describe the way a given company does business. It is the long-term method of using the resources of an organization to achieve profitability and competitive advantage [35]. The business model defines all the key activities of the enterprise that lead to a profit [35]. The model, depending on the company's assumptions, may be based on a different approach to business processes, including the creation of innovations based on closed or open innovations [35]. Open innovation is an idea that determines an open and mutual approach to the process of creating and implementing a new or significantly improved product or service [36]. Open innovation is in opposition to the well-known closed innovation, during which all activities leading to the creation of innovation is initiated and carried out within one company, based on its own expert staff [36]. The concept of closed innovation is theoretically supposed to ensure the company's position as a market leader. However, in practice, it often translates into the fact that innovations become unrealized projects or unsuccessful and costly undertakings [36]. Such misguided innovations in the case of shared mobility systems include, for example, the implementation of an insufficient number of vehicle fleets with high demand, the implementation of electric vehicles in the absence of the necessary infrastructure, or a 
change in the type of provided services by the transition from rentals per minute to typical subscription systems. In contrast, a business model based on open innovations should be characterized by five main terms, which include [9-12]:

- The organization does not only use its own solutions but also uses ideas from its external environment [37];

- The company establishes cooperation with specialists from outside the company;

- The market advantage is gained not by the inventor of a given service or product, but by the one who will improve it properly to meet customer expectations [38];

- Market success is the effective use of available ideas and not their continuous delivery [39];

- Open innovations do not pigeonhole solutions-they do not block the flow of knowledge, skills, licenses, or technology [40].

A business model based on open innovation is called an open business model [36]. Open business models are used to enable an organization to be more effective at creating as well as capturing value. That kind of model is referred to as 'the desirable end state of firm transformation' [41]. Their basic premise is to help create value [41]. It is possible due to having many ideas from outside the organization [40]. Due to the dependence on external resources and the ecosystem, open business models also give the possibility of a wider acquisition of not only ideas but also values that can be implemented in the company [42-47]. Open business models are also highly dynamic models [48]. This is because companies operating in an open business model are constantly actively looking for new opportunities [49], strategic activities [50], and types of cooperation with their stakeholders [51].

The concept of open business models is related to the dynamics of open innovation. However, for the process of developing open innovation in an enterprise to be successful and achieve the assumed results, it is particularly important to proper alignment the currently used business model, to make a comprehensive review of all phases of commercialization of product or service, take into account the non-linearity of the innovation process, define what the innovation will mean for the enterprise, and define limits and moderators the innovation process in the enterprise [52-66].

In the case of digital services, including vehicle-sharing transport services, information about the value of a given service is provided by users almost immediately and around the clock. All the shortcomings, as well as the advantages of a given website, are also much more visible. Therefore, it should be realized that the dynamics of open innovation is much more accelerated than in the case of classic products or services. Therefore, it is important to focus on building an appropriate relationship at the company-customer level and involve customers in improving existing and creating new services [67-73]. This type of relationship is called mutual commitment and is one of the key factors in the proper development of open business models [74-81].

Due to the use of open innovation business models, companies could gain the necessary knowledge within the framework of the established network of contacts and mutual stakeholders [82-85].

Regarding business models, the issues of open innovation are reduced to the idea of value creation [42]. Therefore, their creation must include aspects such as technology, resources, and R\&D availability, as well as unique competencies [86]. Moreover, the innovation should be adapted to the type of industry, legal regulations, and funds [86].

\section{Methods}

Due to the recognition of a niche in research related to the analysis of business models of shared mobility systems in terms of the presence of open innovations in them, it was proposed to conduct research based on the analysis of existing data on the functioning of bike-, car-, and scooter-sharing systems and to conduct interviews with company representatives. Based on those assumptions the own research plan consisted of five steps, was developed. A detailed research plan is presented in Figure 1. 


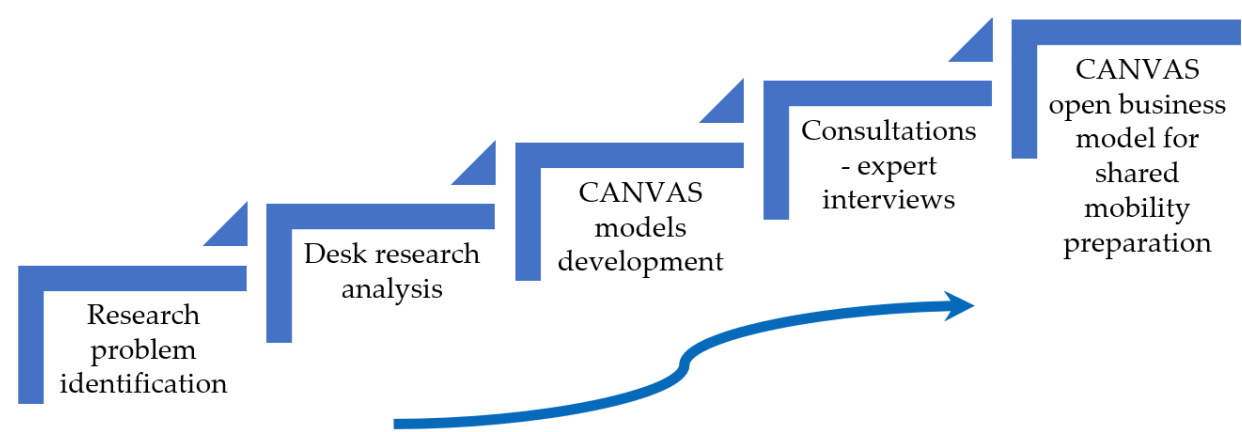

Figure 1. Detailed research plan. Source: author's own elaboration.

The first stage of the research was to identify a research problem. The next step was to select a research sample of the shared mobility systems. The analysis included 9 shared mobility systems: 3 bike-sharing systems operating in the dock and dockless systems; 3 car-sharing systems operating on a free-floating, station-based and hybrid basis; and 3 scooter-sharing systems operating on a free-floating basis. The systems considered operating in 3 European countries included France, Germany, and Poland. The countries were selected in such a way as to show the diversity between the systems functioning among them (which was justified in the discussion).

The proposed research method used to develop business models according to the CANVAS concept was the Desk Research analysis. The Desk Research analysis is a method that boils down to analyzing the records of available data sources, including their compilation, mutual verification, and processing $[87,88]$. When analyzing business models, the focus was on identifying individual elements of the CANVAS model, that is [88]:

- Infrastructure: key activities, key resources, partner network;

- Offering: value propositions;

- Customers: customer segments, channels, customer relationship;

- Finances: cost structure, revenue streams.

The studies were carried out from October to December 2021. The first stage included the development of business models based on the available information on systems, complaints and praise and advice from users, system price lists, and published reports on the functioning of the systems, applications, opinions from the Google Play database [89], websites of the analyzed systems, and their social media networks. The second stage of the research was to consult the developed business models to make them more precise with the representatives of the companies. For this purpose, operators were presented with the received business plans and asked to specify whether they were correct or what elements should be supplemented in them.

In the last stage, the open business model for the shared mobility industry was prepared. The developed common open business model for shared mobility is the result of consultations with companies and empirical research. Their conclusions are not limited to solutions from a specific geographic area, because due to the similar problems of many destinations, they can be successfully used to create open business models in any shared mobility system, both in terms of location and vehicle types. The developed model shows how important it is to remodel key partners, customer structure, and the value offered. The research was conducted in a quantitative form. The obtained results are presented in the following chapter.

\section{Results}

Based on the research carried out by Desk Research, CANVAS models for bike-, car-, and scooter-sharing systems have been developed. During the analysis, it was noticed that regardless of the form of vehicle rental in the system, e.g., free-floating, or stationbased/dockless, these models are based on the same business idea; therefore, collective statements for bike-, car-, and scooter-sharing systems have been prepared. 
The results presented in the form of the business model of bike-sharing systems indicate that these systems have extensive business processes. Particular attention should be paid to the key system partners, including municipalities, urban transport operators, or other business partners. Other important key activities include highly customer-focused and consider research and development activities. It is also worth paying attention to clients using the systems. In addition to local regular users, the users also include food suppliers who are external customers, which is particularly important from the point of view of open innovation. A detailed CANVAS model for bike-sharing is presented in Figure 2.

Key Partners
Bike suppliers and
manufacturers
Municipalities
- Investors
Organizers of collective
transport
- Software vendor
Business partners, incl.
owners of parking lots,
shopping malls, airports
and other places where
bicycles can park or be
returned
- Vehicle service technicians

Business Model Canvas

Key Activities

- Maintaining fleet

Fleet development

Fleet management and its

location and allocation

- Customer Service

- Customer Service

- Marketing

- R\&D activities

Urban development

Urban development

Expanding the
available cities

Key Resources

- Vehicle networked fleet

- IT Platform

Mobile application

- Users

- Staff

Traceable and data-

generating

Data generated by riders

Cost Structure

- Geo-localization system

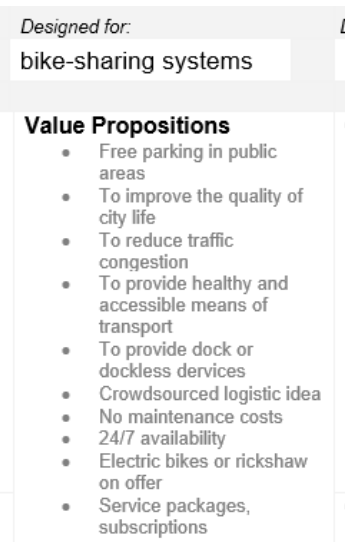

Designed by:

Katarzyna Turoń

Customer Relationships

24/7 online and telephore

customer service

Customer service offices

Easy-to-use application

Affordable and convinient way of travelling

Eco-friendly solution

- Lifestyle

Bikeshare community

Inviting friends option

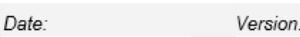

28/12/2021 1

Customer Segments

- Regular users

Occasional users

- Local citizens

- Tourists and trave

Teenagers

Public transport passenger

- Eco-enthusiasts

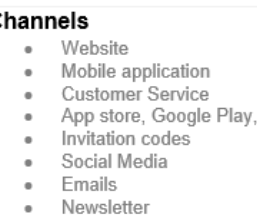

Revenue Streams

Usabcription

- Use-paid

Pre-paid

Rule-braking charges

Possible additional revenues

Figure 2. The bike-sharing business model based on the CANVAS concept. Source: author's own elaboration.

For comparison, car-sharing systems have much less developed areas of both key customers and key activities. The business model is less customer-oriented. Partnerships with local governments and partnerships with public transport operators are missing here. What is more, car-sharing systems have far fewer communication channels, and they do not consider as many key sources as bike-sharing systems. The systems also do not offer the possibility of analyzing data on their vehicle rentals or detailed information on the fleet, which is possible in the case of bike-sharing. In the case of customers, an important factor here is business customers as well as businessmen who can make a valuable contribution to the creation of open innovation. A detailed CANVAS model for car-sharing is presented in Figure 3.

When analyzing scooter-sharing systems, it should be noted that they are like the business model of bike-sharing. Both systems belong to micro-mobility services; therefore, they are more accessible and better distributed within cities. Importantly, however, these systems, compared to bike-sharing, lead to an even wider exposition of their key activities focused on the wide distribution of vehicles. From the point of view of relations with clients of the scooter-sharing system, they are slightly worse than bike-sharing. For the latter, additional opportunities are offered to invite friends and expand the system through viral marketing, which can have a significant impact on spreading open innovation. The 
systems also have fewer revenue streams, making them more affordable for potential users. However, they offer fewer value propositions compared to bike-sharing. A detailed CANVAS model for scooter-sharing is presented in Figure 4.

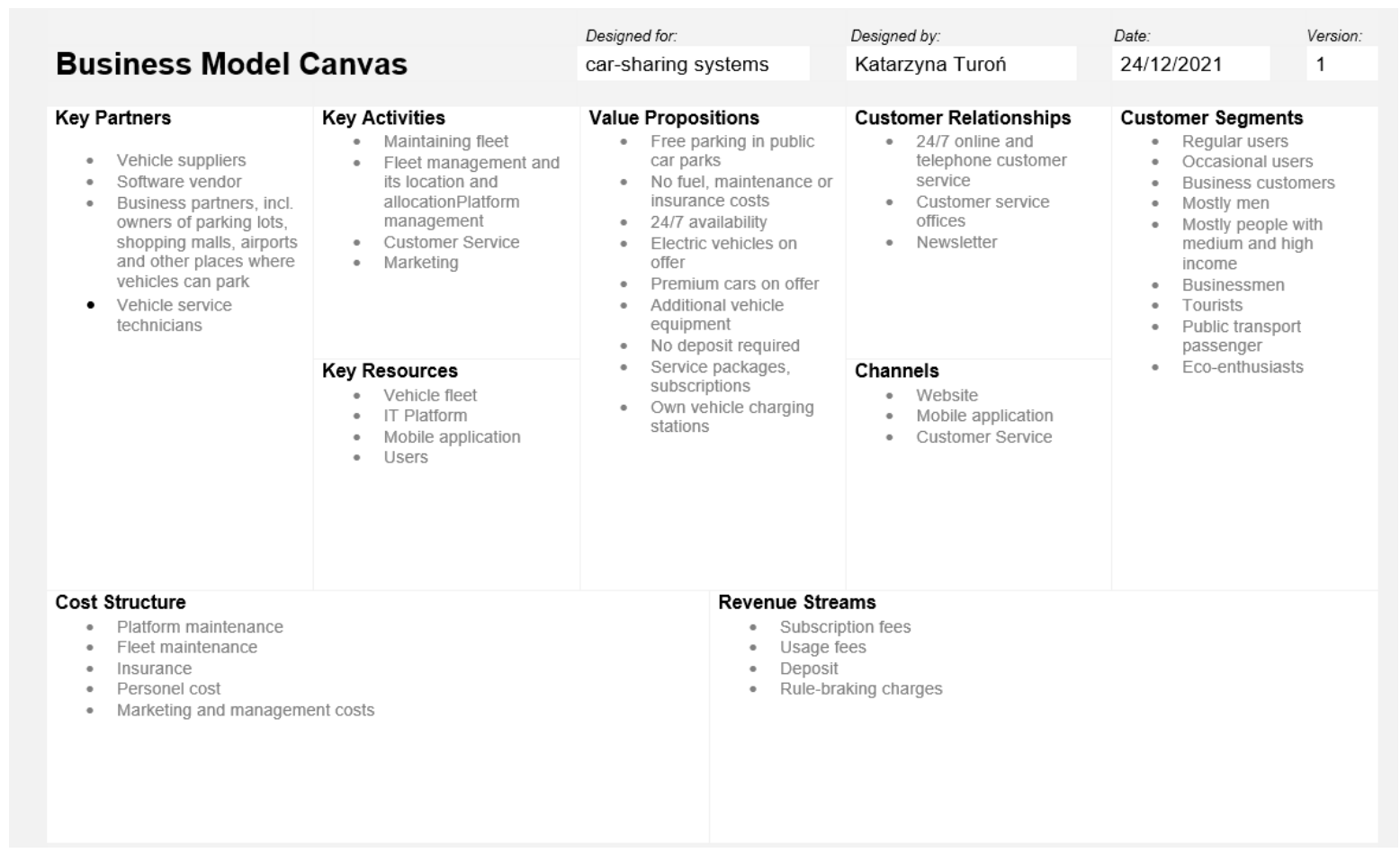

Figure 3. The car-sharing business model based on the CANVAS concept. Source: author's own elaboration.

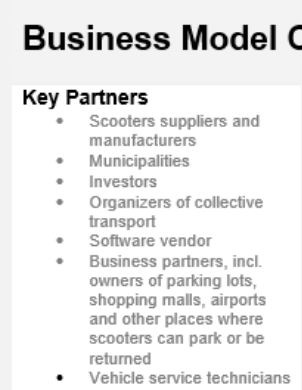

Key Activities

- Maintaining fleet

Fleet management and

- location and allocation

- Customer Service

Customer Support

Marketing

R\&D activities

- Urban development

available cities

Key Resources

Vehicle networked fleet

- IT Platform

- Users

Staff

Traceable and data-

generating

Data generated by riders

Cost Structure

- Platform maintenance and IT infrastrucutre

Maintenance and reconditioning
Physical infrastrucutre costs

Salaries

International expansion

- Insurance

- Personel cost

and management costs

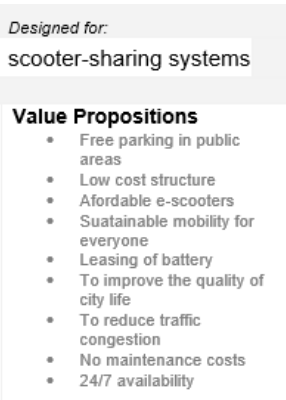

Designed by:

Katarzyna Turoń

Date:

Customer Relationships

$24 / 7$ online and tel
customer service

Customer service offices

Easy-to-use application
Affordable and convinient

Affordable and con
way of travelling

-friendly solution

Lifestyle

Scooter-share community

No maintenance

Channels

- Mobile application

Customer Service

App store, Google Play.

Invitation codes

Emails

Revenue Streams

- Usage fe
Deposit

- Possible additional revenues

Figure 4. The scooter-sharing business model based on the CANVAS concept. Source: author's own elaboration. 
Based on the results obtained, a discussion was conducted along with the proposition of an open model for shared mobility, which is presented in the next chapter.

\section{Discussion}

The CANVAS models developed for shared mobility systems indicate that the model of the bike-sharing service system is the most broad-based. Interestingly, this model is the most extensive in terms of the value proposition. From the point of view of customer care, the systems also offer the opportunity to express users' opinions by creating a community for their brands. Due to this, customers can actively join the process of transforming systems into more open and accessible to users. Moreover, studies have shown that bikesharing can also invite friends and can be promoted more widely through viral marketing. The results show that bike-sharing systems also have the most features of open systems and the possibility of implementing open innovations in them. This is evidenced by, inter alia, R\&D research conducted by operators, data collection, and sharing data about the journeys made, availability of bicycles, or docking stations. It is worth mentioning that bike-sharing operators annually publish reports on the functioning of their systems in each season. In addition, both bike-sharing and scooter-sharing operators willingly cooperate with municipal and city authorities in the scope of providing their services. The effect of this is, for example, designated special places for collecting vehicles. What is more, due to the cooperation, various types of recommendations or policies are created, and the services are improved [90]. Interestingly, in the industry, bike-sharing services, since they are the oldest, use the simplest means of transport, such as bicycles, which seem to be the least innovative [91]. What is more, the systems' analysis shows that they pay special attention to cooperation with key partners, which include external entities, which is particularly important for the development of open innovation and open business models. In addition, an important aspect is that the systems are also used by people representing other companies. This is what happens with food vendors. It is an advantage from the point of view of the open business because this cooperation can be transformed into additional value and propose a separate cooperation model which, in addition to B2B, will also be $\mathrm{B} 2 \mathrm{~B}$. The systems are also among the most environmentally sustainable thanks to the use of environmentally friendly means of transport.

The second system in terms of open innovation is scooter-sharing services. These, in turn, have been considered in recent years have been considered the most innovative due to the use of electric scooters in them and the possibility of using the systems as an ecological last mile transport [92]. Research shows that scooter-sharing operators are eager to collect and analyze travel data. It happens that these data are also partially published by operators. Interestingly, operators are also strongly involved in their cooperation with recipients by establishing relationships. Special user groups are created, special discount codes are offered, and gamification elements are also offered to encourage users to use the services by using viral marketing It is worth mentioning that both in the case of systems offering shared bikes and scooters, these systems cooperate with operators of mobility accelerators and mobility as a service (MaaS) systems. The use of this type of service allows users to find available vehicles through one application, making use more accessible, convenient, and flexible.

Car-sharing system operators are the worst in the ranking. Research results indicate that these systems are the most closed, are reluctant to share data, and engage in the most closed marketing. The systems are less customer-oriented in comparison to bikeand scooter-sharing solutions. What is more, they also pay less attention to cooperation with their key partners. Importantly, car-sharing operators are also the least interested in joining MaaS [93]. In this case, it is worth paying attention to cities with intensively developed MaaS systems and the offer of services provided there. Interestingly, it may turn out that despite the possibility of choosing many operators by one application, the interest in services on the part of users is growing. An excellent example in this regard is Berlin, where, with a well-developed MaaS system, there are 7 service operators on the market [94]. 
What is more, car-sharing operators consider their ideas to be copied by the competition as the main disadvantage [34]. In my opinion, this is an unfair fear because, regardless of the type of services provided, car-sharing systems are based on the same principle of operation. What is more, car-sharing operator's concern is the possibility of disclosing classified information about the company. Based on that assumption they do not want to cooperate with external partners. In my opinion, operators do not have to share data that are considered confidential. Nevertheless, data relating to, for example, the location of cars cannot be considered confidential. Such data are already owned by mobility accelerators and are shared with the vehicle API. Other data that might be too sensitive to share may be covered by additional protective intellectual property.

From the geographical point of view, the research shows that single aspects of open innovation occur in all operators from each of the three analyzed countries, i.e., Germany, France, and Poland. However, these activities, as indicated in the results, mainly relate to bike-sharing and scooter-sharing. When it comes to the background of shared mobility systems functioning in these areas, it is worth pointing out that these countries were selected on purpose due to the level of advancement of the systems present there. Germany and France are countries with great traditions in shared mobility services. It is worth mentioning that Germany is the most developed country in terms of the availability of shared mobility services [95]. They are also characterized by the greatest competition on the market, as well as a tendency to implement technological innovations in new mobility systems, which may be a response to the updated models. It is worth mentioning that in Germany there are car-sharing operators who are very much involved in cooperation with the socio-economic environment-e.g., Cambio, Flinkster, and PMC. However, they were not included in the analyzes. In turn, France currently strongly focuses on the development of activities in the field of bicycle tourism and micro-mobility, hence the noticeable changes in bike-sharing systems. Moreover, trends indicate that the pandemic had a significant impact on the significant development of micro-mobility systems [96], which the conducted research reflects in the presented business models. In turn, Poland is a relatively new shared mobility market [97]. Importantly, despite the small traditions with shared mobility systems, the Polish market is famous for the existence of many service operators and very intense competition [98].

Based on the obtained results, Desk Research, and basic assumptions regarding open innovation, the CANVAS business model for an open shared mobility system was developed. The open sharing model is the evolution of the classic model with an indication of the aspects that operators of all types of shared mobility services can use. The model consists of single activities in the field of open innovation currently used by companies and with developed solutions that companies can additionally consider when creating an open business model. It is a more extensive form that includes the possibility of connecting to MaaS systems, sharing vehicle data, or establishing cooperation with local authorities or universities, i.e., issues that are very often the main problems in the development of MaaS systems. The detailed CANVAS model is shown in Figure 5.

The proposed model has elements that, depending on the intentions of the operator, can be used in various areas of the company's operation. The model was developed in such a way that each of the indicated selected factors will be able to increase the openness of the business model of services.

The proposed model focuses a lot of attention on key partners, emphasizing their important role in the case of open businesses. The model points to the importance of public partnership [99]. They also emphasize the value of cooperation with universities that positively influence the development of open innovation [100]. The model also indicates important key activities, among which it shows viral marketing, which contributes to improving customer awareness of the brand [101]. An important factor is also the quality management of the services offered, thanks to which, based on an appropriate learning algorithm, it is possible to increase the sales effectiveness [102]. 


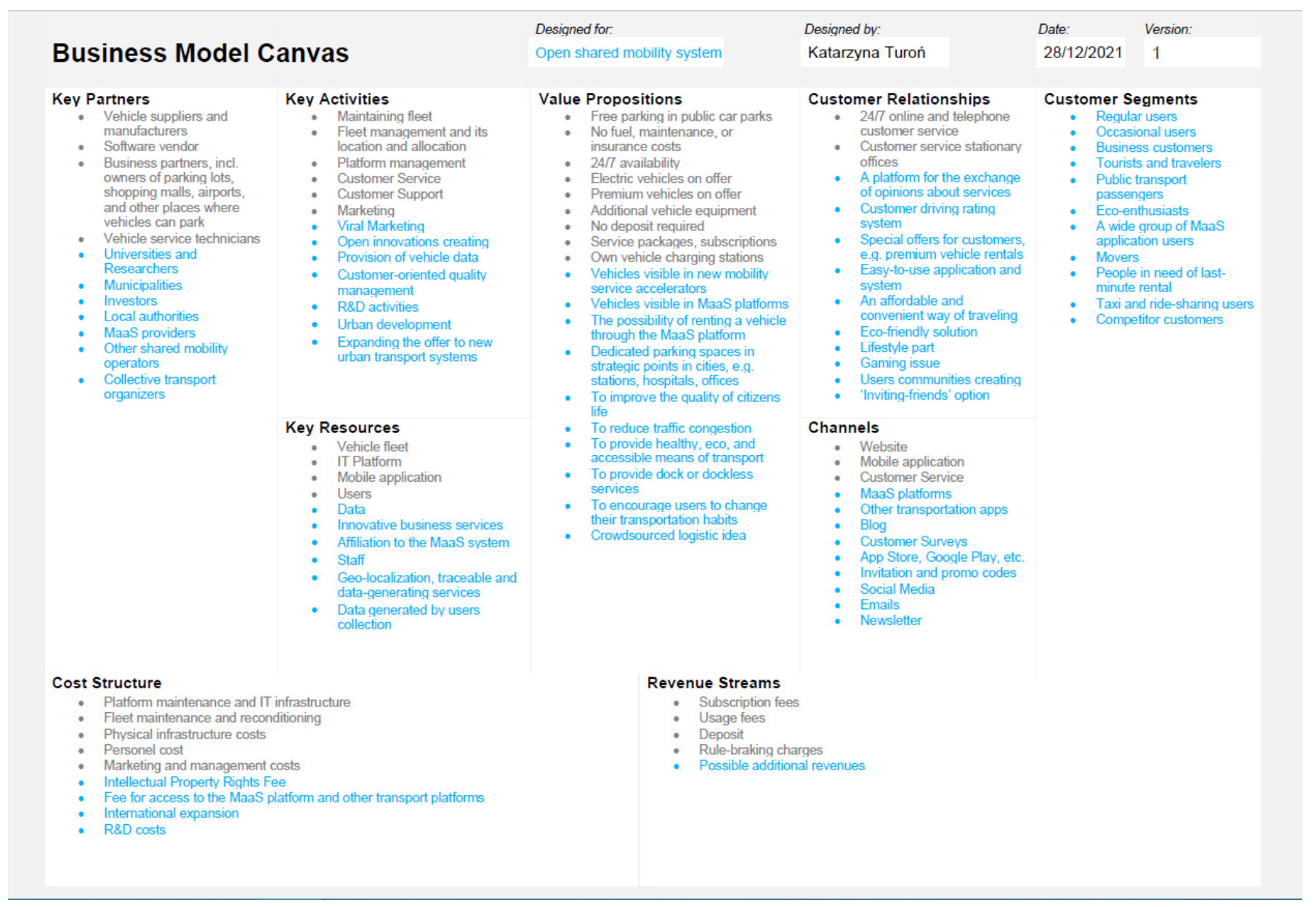

Figure 5. Open shared mobility business model based on the CANVAS concept. Source: author's own elaboration.

From the value proposition point of view, the model focuses on the aspects of connecting to MaaS systems and mobility accelerators that increase brand recognition, improve its availability and flexibility [103].

In terms of customer relations, the model proposes the creation of platforms for mutual communication and the exchange of ideas. This type of solution not only fosters business development but can also translate into reducing transport barriers or reducing the problem of transport exclusion [104].

From the point of view of key customers, it would be important to re-segment them. It is especially important to pay attention to companies using the services of the systemsit is worth developing special offers targeted at business. It is also worth checking the expectations of businessmen or teenagers using the systems and rebuilding the offered value, accordingly, thus creating a service focused on the real needs of customers. This type of analysis will identify customer roles and levels of commitment at different stages of the innovation process [105]. Then it will be possible to assess the level of customer involvement in open innovation.

Key resources for open innovation are particularly important from a data point of view. Firms should gradually focus on developing data-sharing practices and implementing policies that value data for its sensitivity. This action is particularly important, especially from the point of view of potential accession to MaaS or mobility accelerators, or possible cooperation with external partners.

In the case of distribution channels, it is important to pay attention to the possibilities that will keep you in constant contact with customers. This will allow for constant monitoring of the quality of services and their rapid improvement. 
In terms of the cost structure, the model highlights the costs that may be incurred in the case of implementing open innovations. Before taking steps to start making changes, companies should analyze them according to their resources and decide what level of innovation the organization can afford. Research by, e.g., Greco or Nguyen et al. indicates that companies that have implemented open innovations have not suffered from this budget $[106,107]$.

It is worth remembering that the selection of even individual activities indicated in the model of the open shared mobility business model is a step to increase the dynamics of the development of open innovations in the entire new mobility industry, and thus a chance for better implementation of the goals of sustainable development.

\section{Conclusions}

In conclusion, the conducted research indicated that the subject of open innovation, and thus the elements of open business models, is not well developed in shared mobility systems. As well as the dynamics of business models and the development of innovation in enterprises are disturbed. Research shows that the most opposing open innovations are car-sharing operators, while the most innovative systems turned out to be bike-sharing systems.

Since the following years, especially 2022, are considered to be the year of data integration, data sharing, and MaaS development [108], to facilitate the transition to a more open business model by operators, a proprietary model of an open vehicle sharing system based on the concept of open innovation and data sharing was proposed.

The developed business model fills the research gap on open business models in the new mobility industry. The model will allow operators to indicate aspects that they should pay attention to when building relationships with their recipients. Its use may positively affect the level of interest in services through their greater availability and flexibility and thus translate into the sustainability of transport in cities. What is more, it also helps monitoring of customer needs to allow for faster creation of open innovations, and will improve their flow in the enterprise, which will also affect the business model and may translate into better development of sustainable transport services in cities.

The article has some limitations related to:

- The geographical area (European area) where selected shared mobility companies operate;

- The number of systems considered - in particular the number of operators willing to take part in the validation of business models;

- The difficulty of data availability and the presence of incomplete data;

- The occurrence of situations of reluctance to share among operators the details of their operating practices;

- Failure to present specific names of companies which, due to the GDPR, asked not to publish their identity;

- Generalization of results, which may be different with a larger research sample, with which the author plans to research in the future.

Despite this, the results can be considered reliable as the analysis includes companies from countries with very large car-sharing traditions as well as emerging markets.

In the next articles, the author plans to expand her research to new geographic areas to be able to compare the approach to open innovation, data sharing open business models also at the global level. Moreover, the author would like to develop detailed guidelines for the implementation of the open innovation model in shared mobility systems. The author also plans to perform a SWOT analysis on the developed models to help organizations identify strengths, weaknesses, opportunities, and threats related to business competition or new open innovations implementations.

Funding: This research received no external funding.

Institutional Review Board Statement: Not applicable. 
Informed Consent Statement: Not applicable.

Data Availability Statement: The data presented in this study are available on request from the corresponding author. The data are not publicly available due to privacy.

Conflicts of Interest: The author declares no conflict of interest.

\section{References}

1. Shared Mobility Market by Service (Ride Hailing, Bike Sharing, Ride Sharing and Car Sharing), Vehicle (Passenger Cars, LCVs, Busses \& Coaches and Micro mobility), Business Model (P2P, B2B and B2C) and Power Source (Fuel Powered, Hybrid Electric Vehicle (HEV), Plug-in Hybrid Electric Vehicle (PHEV) and Battery Electric Vehicle (BEV)): Global Opportunity Analysis and Industry Forecast, 2021-2027. Available online: https:/ /www.alliedmarketresearch.com/shared-mobility-market-A10179 (accessed on 27 January 2022).

2. Novikova, O. The Sharing Economy and the Future of Personal Mobility: New Models Based on Car Sharing. Technol. Innov. Manag. Rev. 2017, 7, 27-31. [CrossRef]

3. Hjorteset, M.A.; Böcker, L.; Røe, P.G.; Wessel, T. Intraurban geographies of car sharing supply and demand in Greater Oslo, Norway. Transp. Res. Part D Transp. Environ. 2021, 101, 103089. [CrossRef]

4. Boyac1, B.G.; Zografos, K.G. Investigating the effect of temporal and spatial flexibility on the performance of one-way electric carsharing systems. Transp. Res. Part B Methodol. 2019, 129, 244-272. [CrossRef]

5. Natalia Kireeva, N.; Zavyalova, D.; Saginovaa, O.; Zavyalov, N. Car Sharing Market Development in Russia. Transp. Res. Procedia 2021, 54, 123-128. [CrossRef]

6. Cruz, S.S.; Paulino, S.R. Experiences of Innovation in Public Services for Sustainable Urban Mobility. J. Urban Manag. 2021. Available online: https://www.sciencedirect.com/science/article/pii/S2226585621001072?via\%3Dihub (accessed on 6 January 2022).

7. Reck, D.J.; Haitao, H.; Guidon, S.; Axhausen, K.W. Explaining shared micromobility usage, competition and mode choice by modelling empirical data from Zurich, Switzerland. Transp. Res. Part C Emerg. Technol. 2021, 124, 102947. [CrossRef]

8. Saeed, T.U.; Alabi, B.N.; Labi, S. Preparing road infrastructure to accommodate connected and automated vehicles: System-level perspective. J. Infrastruct. Syst. 2021, 27, 06020003. [CrossRef]

9. Terrien, C.; Maniak, R.; Chen, B.; Shaheen, S. Good practices for advancing urban mobility innovation: A case study of one-way carsharing. Res. Transp. Bus. Manag. 2016, 20, 20-32. [CrossRef]

10. Esztergár-Kiss, D.; Kerényi, T. Creation of mobility packages based on the MaaS concept. Travel Behav. Soc. 2020, 21, 307-317. [CrossRef]

11. Turoń, K.; Kubik, A. Business Innovations in the New Mobility Market during the COVID-19 with the Possibility of Open Business Model Innovation. J. Open Innov. Technol. Mark. Complex. 2021, 7, 195. [CrossRef]

12. Jamal, S.; Chowdhury, S.; Newbold, B.K. Transport preferences and dilemmas in the post-lockdown (COVID-19) period. Findings from a qualitative study of young commuters in Chaka, Banghadesh. Case Stud. Transp. Policy 2022, in press. [CrossRef] [PubMed]

13. Xie, K.; Liang, B.; Dulebenets, M.A.; Mei, Y. The Impact of Risk Perception on Social Distancing during the COVID-19 Pandemic in China. Int. J. Environ. Res. Public Health 2020, 17, 6256. [CrossRef] [PubMed]

14. Yuan, J.; Zou, H.; Xie, K.; Dulebenets, M.A. An Assessment of Social Distancing Obedience Behavior during the COVID-19 Post-Epidemic Period in China: A Cross-Sectional Survey. Sustainability 2021, 13, 8091. [CrossRef]

15. Fabiani, C.; Longo, S.; Pisello, A.L.; Cellura, M. Sustainable production and consumption in remote working conditions due to COVID-19 lockdown in Italy: An environmental and user acceptance investigation. Sustain. Prod. Consum. 2021, 28, $1757-1771$. [CrossRef]

16. Shokouhyar, S.; Shokoohyar, S.; Sobhani, A.; Jafari Gorizi, A.J. Shared mobility in post-COVID era: New challenges and opportunities. Sustain. Cities Soc. 2021, 67, 102714. [CrossRef]

17. Awad-Núñez1, S.; Julio, R.; Gomez, J.; Moya-Gómez, B.; González, J.S. Post-COVID-19 travel behaviour patterns: Impact on the willingness to pay of users of public transport and shared mobility services in Spain. Eur. Transp. Res. Rev. 2021, 13, 20. [CrossRef]

18. Rahimi, E.; Shabanpour, R.; Shamshiripour, A.; Mohammadian, A. Perceived risk of using shared mobility services during the COVID-19 pandemic. Transp. Res. Part F Traffic Psychol. Behav. 2021, 81, 271-281. [CrossRef]

19. Corazza, M.V.; Moretti, L.; Forestieri, G.; Galiano, G. Chronicles from the new normal: Urban planning, mobility and land-use management in the face of the COVID-19 crisis. Transp. Res. Interdiscip. Perspect. 2021, 12, 100503. [CrossRef]

20. Khorram-Manesh, A.; Dulebenets, M.A.; Goniewicz, K. Implementing Public Health Strategies-The Need for Educational Initiatives: A Systematic Review. Int. J. Environ. Res. Public Health 2021, 18, 5888. [CrossRef]

21. Chivite Cebolla, M.P.; Vázquez, J.J.; Chivite Cebolla, C.M. Collaborative economy, a society service? Involvement with ethics and the common good. Bus. Ethics Environ. Responsib. 2021, 30, 657-674. [CrossRef]

22. Owyang, J.; Tran, C.Y.; Silva, C. The Collaborative Economy. Altimeter Res. 2013, 1-27. Available online: https:/ /www.slideshare. net/Altimeter/the-collaborative-economy (accessed on 27 January 2022).

23. Sutherland, W.Y.; Jarrahi, M.H. The sharing economy and digital platforms: A review and research agenda. Int. J. Inf. Manag. 2018, 43, 328-341. [CrossRef] 
24. Jorge-Vázquez, J. La economía colaborativa en la era digital: Fundamentación teórica y alcance económico. In Economía Digital y Colaborativa: Cuestiones Económicas y Jurídicas; Náñez, S.L., Ed.; Università degli Studì Suor Orsola Benincasa, Eurytonpress: Naples, Italy, 2019.

25. Becker, H.; Balac, M.; Ciari, F.; Axhausen, K.W.; Kay, W. Assessing the welfare impacts of Shared Mobility and Mobility as a Service (MaaS). Transp. Res. Part A Policy Pract. 2020, 131, 228-243. [CrossRef]

26. Hasselwander, M.; Bigotte, J.F.; Fonseca, M. Understanding platform internationalisation to predict the diffusion of new mobility services. Res. Transp. Bus. Manag. 2021, 100765. [CrossRef]

27. Cohen, B.; Almirall, E.; Chesbrough, H. The City as a Lab: Open Innovation Meets the Collaborative Economy. Calif. Manag. Rev. 2016, 59, 5-13. [CrossRef]

28. Hansen, E.; Gomm, M.; Reichwald, R. Providing Sustainable Mobility for All Through Open Innovation: The Case of gopping.de. In Proceedings of the 39th World Congress of the International Institute of Sociology, Yerevan, Armenia, 11-14 June 2009. Available online: https:/ / papers.ssrn.com/sol3/papers.cfm?abstract_id=1440746 (accessed on 15 September 2021).

29. Münzel, K.; Boon, W.; Frenken, K.; Vaskelainen, T. Carsharing business models in Germany: Characteristics, success and future prospects. Inf. Syst. E-Bus. Manag. 2018, 16, 271-291. [CrossRef]

30. Cohen, B.; Kietzmann, J. Ride On! Mobility Business Models for the Sharing Economy. Organ. Environ. 2014, 27, 279-296. [CrossRef]

31. Frenken, K. Political economies and environmental futures for the sharing economy. Philos. Trans. R. Soc. A Math. Phys. Eng. Sci. 2017, 375, 20160367. [CrossRef] [PubMed]

32. Shaheen, S.; Cohen, A. Carsharing and personal vehicle services: Worldwide market developments and emerging trends. Int. J. Sustain. Transp. 2013, 7, 5-34. [CrossRef]

33. Coenegrachts, E.; Beckers, J.; Vanelslander, T.; Verhetsel, A. Business Model Blueprints for the Shared Mobility Hub Network. Sustainability 2021, 13, 6939. [CrossRef]

34. Turoń, K.; Kubik, A. Open Innovation in the Shared Mobility Market. J. Open Innov. Technol. Mark. Complex. 2021, 7, 212. [CrossRef]

35. Teece, D.J. Business Models. Business Strategy and Innovation. Long Range Plan. 2010, 43, 172-194. [CrossRef]

36. Chesbrough, H. Open Business Models: How to Thrive in the New Innovation Landscape; Harvard Business Press: Brighton, MA, USA, 2006.

37. Sarasini, S.; Langeland, O. Business model innovation as a process for transforming user mobility practices. Environ. Innov. Soc. Transit. 2021, 39, 229-248. [CrossRef]

38. Wiprächtiger, D.; Narayanamurthy, G.; Moser, R.; Sengupta, T. Access-based business model innovation in frontier markets: Case study of shared mobility in Timor-Leste. Technol. Forecast. Soc. Change 2019, 143, 224-238. [CrossRef]

39. Weiblen, T. The Open Business Model: Understanding an Emerging Concept. J. Multi. Bus. Model Innov. Technol. 2016, 2, 35-66. [CrossRef]

40. Peñarroya-Farell, M.; Miralles, F. Business Model Dynamics from Interaction with Open Innovation. J. Open Innov. Technol. Mark. Complex. 2021, 7, 81. [CrossRef]

41. Enkel, E.; Gassmann, O.; Chesbrough, H. Open R\&D and open innovation: Exploring the phenomenon. RED Manag. 2009, 39, 311-316.

42. Khumalo, M.; Lingen, E.V. The Open Business Model In A Dynamic Business Environment: A Literature Review. S. Afr. J. Ind. Eng. 2017, 28, 147-160. [CrossRef]

43. West, J.; Bogers, M. Leveraging External Sources of Innovation: A Review of Research on Open Innovation. J. Prod. Innov. Manag. 2014, 31, 814-831. [CrossRef]

44. Visnjic, I.; Neely, A.; Jovanovic, M. The path to outcome delivery: Interplay of service market strategy and open business models. Technovation 2019, 72, 46-59. [CrossRef]

45. Moradi, E.; Mohammadbagher Jafari, S.; Mohammadi Doorbash, Z.; Mirzaei, A. Impact of organizational inertia on business model innovation, open innovation and corporate performance. Asia Pac. Manag. Rev. 2021, 26, 171-179. [CrossRef]

46. Najar, T. Antecedents to open business model in the ICT-based sectors. J. High Technol. Manag. Res. 2020, 31, 100388. [CrossRef]

47. Tsutsui, Y.; Yamada, N.; Mitake, Y.; Sholihah, M.; Shimomura, Y. A Strategic Design Guideline for Open Business Models. Int. J. Autom. Technol. 2020, 14, 678-689. [CrossRef]

48. Safdari Ranjbar, M.; Manteghi, M.; Tavakoli, G. Open innovation, a comprehensive overview of concepts, approaches, trends and key success factors. Technol. Growth 2014, 10, 10-17.

49. Purdy, M.; Robinson, M.; Wei, K. Three new business models for "the open firm". Strategy Leadersh. 2012, 40, 36-41. [CrossRef]

50. Gurca, A.; Bagherzadeh, M.; Markovic, S.; Koporcic, N. Managing the challenges of business-to-business open innovation in complex projects: A multi-stage process model. Ind. Mark. Manag. 2021, 94, 202-215. [CrossRef]

51. Ottonicar, S.L.; Arraiza, P.M.; Fabiano, A. Opening Science and Innovation: Opportunities for Emerging Economies. Foresight and STI Governance. 2020. Available online: https://www.semanticscholar.org/paper/Opening-Science-and-Innovation\%3AOpportunities-for-Ottonicar-Arraiza/bf0aca6372deb1ba22cbbb36cafa536ee7dd2174 (accessed on 24 December 2021).

52. Baldwin, C.Y.; von Hippel, E. Modeling a paradigm shift: From producer innovation to user and open collaborative innovation. Organ. Sci. 2011, 22, 1399-1417. [CrossRef]

53. Berkhout, A.J.; Hartmann, D.; van der Duin, P.; Ortt, R. Innovating the innovation process. Int. J. Technol. Manag. 2006, 34, 390-404. [CrossRef] 
54. Rohrbeck, R.; Hölzle, K.; Gemünden, H.G. Opening up for competitive advantage: How Deutsche Telekom creates an open innovation ecosystem. RED Manag. 2009, 39, 420-430.

55. Granstrand, O.; Sjölander, S. Managing innovation in multitechnology corporations. Res. Policy 1990, 19, 35-60. [CrossRef]

56. Wincent, J.; Anokhin, S.; Boter, H. Network board continuity and effectiveness of open innovation in Swedish strategic small-firm networks. RED Manag. 2009, 39, 55-67.

57. Spaeth, S.; Stuermer, M.; von Krogh, G. Enabling knowledge creation through outsiders: Towards a push model of open innovation. Int. J. Technol. Manag. 2010, 52, 411-431. [CrossRef]

58. Dodgson, M.; Gann, D.; Salter, A. The role of technology in the shift towards open innovation: The case of Procter \& Gamble. RED Manag. 2006, 36, 3.

59. Nonaka, I.; Takeuchi, H. The Knowledge-Creating Company: How Japanese Companies Create the Dynamics of Innovation; Oxford University Press: Oxford, UK, 1995.

60. Rizova, P. Are you networked for successful innovation? MIT Sloan Manag. Rev. 2006, 47, 49-55.

61. Belussi, F.; Sammarra, A.; Sedita, S.R. Learning at the boundaries in an "Open Regional Innovation System": A focus on firms' innovation strategies in the Emilia Romagna life science industry. Res. Policy 2010, 39, 710-721. [CrossRef]

62. Abulrub, A.-H.; Lee, J. Open innovation management: Challenges and prospects. Procedia-Soc. Behav. Sci. 2012, 41, 130-138. [CrossRef]

63. McGahan, A.M.; Bogers, M.; Chesbrough, H.; Holgersson, M. Tackling Societal Challenges with Open Innovation. Calif. Manag. Rev. 2021, 63, 49-61. [CrossRef]

64. Bogers, M.; Chesbrough, H.; Heaton, S.; Teece, D.J. Strategic Management of Open Innovation: A Dynamic Capabilities Perspective. Calif. Manag. Rev. 2019, 62, 77-94. [CrossRef]

65. Schoemaker, P.J.H.; Heaton, S.; Teece, D. Innovation, Dynamic Capabilities, and Leadership. Calif. Manag. Rev. 2018, 61, 15-42. [CrossRef]

66. Christensen, J.F.; Olesen, M.H.; Kjær, J.S. The industrial dynamics of Open Innovation-Evidence from the transformation of consumer electronics. Res. Policy 2005, 34, 1533-1549. [CrossRef]

67. Wantabe, C.; Shin, J.; Heikkinen, J.; Tarasyev, A. Optimal Dynamics of Functionality Development in Open Innovation. IFAC Proc. Vol. 2009, 42, 173-178.

68. Schmeiss, J.; Hoelzle, K.; Tech, R. Designing Governance Mechanisms in Platform Ecosystems: Addressing the Paradox of Openness through Blockchain Technology. Calif. Manag. Rev. 2019, 62, 121-143. [CrossRef]

69. Bogers, M.; Afuah, A.; Bastian, B. Users as Innovators A Review, Critique, and Future Research Directions. J. Manag. 2010, 36, 857-875. [CrossRef]

70. Muñoz, P.; Cohen, B. A Compass for Navigating Sharing Economy Business Models. Calif. Manag. Rev. 2018, 61, 114-147. [CrossRef]

71. Iivari, M.; Ahokangas, P.; Matinmikko-Blue, M.; Yrjölä, S. Opening Closed Business Ecosystem Boundaries With Digital Platforms. In Emerging Ecosystem-Centric Business Models for Sustainable Value Creation; IGI Global: Hershey, PA, USA, 2022 ; pp. 67-69. [CrossRef]

72. Adner, R.; Kapoor, R. Value Creation in Innovation Ecosystems: How the Structure of Technological Interdependence Affects Firm Performance in New Technology Generations. Strateg. Manag. J. 2010, 31, 306-333. [CrossRef]

73. Chesbrough, H.; Kim, S.; Agogino, A. Chez Panisse: Building an Open Innovation Ecosystem. Calif. Manag. Rev. 2014, 56, 144-171. [CrossRef]

74. Berglund, H.; Sandström, C. Business model innovation from an open systems perspective: Structural challenges and managerial solutions. Int. J. Prod. Dev. 2013, 18, 274-285. [CrossRef]

75. Blankenburg Holm, D.; Eriksson, K.; Johanson, J. Creating Value through Mutual Commitment to Business Network Relationships. Strateg. Manag. J. 1999, 20, 467-486. [CrossRef]

76. Chetty, S.; Eriksson, K. Mutual commitment and experiential knowledge in mature international business relationship. Int. Bus. Rev. 2002, 11, 305-324. [CrossRef]

77. Chopra, A.; Singh, M. Specifying and applying commitment-based business patterns. In Proceedings of the AAMAS'11: The 10th International Conference on Autonomous Agents and Multiagent Systems, Taipei, Taiwan, 2-6 May 2011; Volume 2, pp. 475-482. Available online: https:/ /ifaamas.org/Proceedings/aamas2011/papers/A4_R55.pdf (accessed on 6 January 2022).

78. Duenas, M.; Mangen, C. Trust in international cooperation: Emotional and cognitive trust complement each other over time. Crit. Perspect. Account. 2021, 102328. [CrossRef]

79. Luczak, J.; Tran, M.-C. University-Real Estate Industry Cooperation in Open Innovation in the Topic of Walkability (breakout presentation). J. Transp. Health 2017, 7, S54. [CrossRef]

80. Okano-Heijmans, M.; Vosse, W. Promoting open and inclusive connectivity: The case for digital development cooperation. Res. Glob. 2021, 3, 100061. [CrossRef]

81. Xie, X.; Wang, H. How can open innovation ecosystem modes push product innovation forward? An fsQCA analysis. J. Bus. Res. 2020, 108, 29-41. [CrossRef]

82. Chesbrough, H.W. Open Innovation: The New Imperative for Creating and Profiting from Technology; Harvard Business School Press: Boston, MA, USA, 2003; ISBN 978-1578518371.

83. West, J.; Lakhani, K.R. Getting Clear About Communities in Open Innovation. Ind. Innov. 2008, 15, 223-231. [CrossRef] 
84. Chesbrough, H.; Bogers, M. Explicating open innovation: Clarifying an emerging paradigm for understanding innovation. In New Frontiers in Open Innovation; Chesbrough, H., Vanhaverbeke, W., West, J., Eds.; Oxford University Press: Oxford, UK, 2014; pp. 3-28.

85. Kirschbaum, R. Open Innovation In Practice. Res.-Technol. Manag. 2005, 48, 24-28. [CrossRef]

86. Jabłoński, M. Kształtowanie Modeli Biznesu w Procesie Kreacji Wartości Przedsiębiorstw; Warsaw: Difin, Poland, 2013.

87. Whyte, W.H. The Social Life of Small Urban Spaces; Project for Public Spaces: New York, NY, USA, 2001.

88. Gehl, J.; Svarre, B. How to Study Public Life? Island Press: Washington, DC, USA, 2013.

89. Google Play Database. Available online: https://play.google.com/store/apps/details?id=com.luckydroid.droidbase\&hl=pl\&gl= US (accessed on 10 October 2021).

90. Osterwalder, A.; Pigneur, Y.; Clark, T. Business Model Generation: A Handbook For Visionaries, Game Changers, and Challengers; Strategyzer Series; John Wiley \& Sons: Hoboken, NJ, USA, 2010.

91. Matyja, T.; Kubik, A.; Stanik, Z. Possibility to Use Professional Bicycle Computers for the Scientific Evaluation of Electric Bikes: Trajectory, Distance, and Slope Data. Energies 2022, 15, 758. [CrossRef]

92. Long, T.B.; van Waes, A. When bike sharing business models go bad: Incorporating responsibility into business model innovation. J. Clean. Prod. 2021, 297, 126679. [CrossRef]

93. Carrese, S.; D'Andreagiovanni, F.; Giacchetti, T.; Nardin, A.; Zamberlan, L. A Beautiful Fleet: Optimal Repositioning in E-scooter Sharing Systems for Urban Decorum. Transp. Res. Procedia 2021, 52, 581-588. [CrossRef]

94. Berlin Official Website. Available online: https://www.berlin.de/en/getting-around/carsharing/ (accessed on 24 December 2021).

95. Wittwer, R.; Hubrich, S. Free-Floating Carsharing Experiences in German Metropolitan Areas. Transp. Res. Procedia 2018, 33, 323-330. [CrossRef]

96. Bouhouras, E.; Basbas, S.; Ftergioti, S.; Paschalidis, E.; Siakantaris, H. COVID-19's Pandemic Effects on Bike Sharing Systems: A New Reality for Urban Mobility? Appl. Sci. 2022, 12, 1230. [CrossRef]

97. Mindur, L.; Sierpiński, G.; Turoń, K. Car-Sharing Development-Current State and Perspective. Logist. Transp. 2018, 39, 5-14.

98. Neumann, T. The Impact of Carsharing on Transport in the City. Case Study of Tri-City in Poland. Sustainability 2021, 13, 688. [CrossRef]

99. Mergel, I. Opening Government: Designing Open Innovation Processes to Collaborate With External Problem Solvers. Soc. Sci. Comput. Rev. 2015, 33, 599-612. [CrossRef]

100. Sara Fernández-López, S.; Astray, B.P.; Rodeiro-Pazos, D.; Calvo, N. Are firms interested in collaborating with universities? An open-innovation perspective in countries of the South West European Space. Serv. Bus. 2014, 9, 637-662. [CrossRef]

101. Skrob, J.R. Open Source and Viral Marketing the Viral Marketing Concept as a Model for Open Source Software to Reach the Critical Mass for Global Brand Awareness Based on the Example of TYPO3. Available online: http://citeseerx.ist.psu.edu/ viewdoc/download?doi=10.1.1.494.8779\&rep=rep1\&type=pdf (accessed on 27 January 2022).

102. Roldán Bravo, M.I.; Llorens Montes, F.J.; Moreno, R. Open innovation and quality management: The moderating role of nterorganizational IT infrastructure and complementary learning styles. Prod. Plan. Control 2017, 28, 1-14. [CrossRef]

103. Le Pira, M.; Tavasszy, L.A.; Homem de Almeida Correia, G.; Ignaccolo, M.; Inturri, G. Opportunities for integration between Mobility as a Service (MaaS) and freight transport: A conceptual model. Sustain. Cities Soc. 2021, 74, 103212. [CrossRef]

104. Turoń, K. Social barriers and transportation social exclusion issues in creating sustainable car-sharing systems. Entrep. Sustain. Issues 2021, 9, 10-22. [CrossRef]

105. Vaisnore, A.; Petraite, M. Customer Involvement into Open Innovation Processes: A Conceptual Model. Soc. Sci. 2011, 73, 62-73. [CrossRef]

106. Greco, M.; Grimaldi, M.; Cricelli, L. Benefits and costs of open innovation: The BeCO framework. Technol. Anal. Strateg. Manag. 2019, 1, 53-66. [CrossRef]

107. Nguyen, T.; Huang, F.; Tian, X. A Meta-Analysis of the Impact of Open Innovation on Performance. J. Manag. Organ. 2021, 1-18. Available online: https://www.cambridge.org/core/journals/journal-of-management-and-organization/article/abs/ metaanalysis-of-the-impact-of-open-innovation-on-performance/FF995E5012F4C5D757AFE3678E0A5142 (accessed on 6 January 2022)

108. Bellan, R. Micromobility in 2022: Refined, Mature and Packed Full of Tech. Techcrunch Portal. Available online: https:/ / techcrunch.com/2021/12/27/micromobility-in-2022-refined-mature-and-packed-full-of-tech/?fbclid=IwAR1 -HZhgXalGkkd35GXhblhmOLHcqCle4xyxBvbv0polr14RWN8SSGZzAuA (accessed on 28 December 2021). 